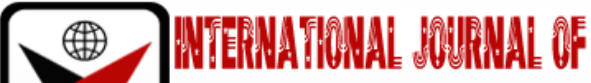

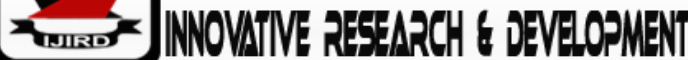

ISSN 2278-0211 (Online)

\section{Impact of Perceived Value on Customer Satisfaction among Mobile Phone Users in Selected Public Universities in Kenya}

\author{
Dr. Kennedy Ntabo Otiso
}

Senior Lecturer, Department of Business Administration and Management Science, School of Business, Koitaleel Samoei University College, Kenya

\begin{abstract}
:
Organizations need to understand what kind of service or products it offers, and for whom and as such organizations have embraced the concept customer relationship management practices since it focuses on managing relationship between its current and prospective customer base hence helping in building long lasting relationships which consequently give the organization the joy of retained customers. The specific objectives of study were; to determine the influence of Perceived Value on customer satisfaction. The study was guided by the social exchange theory which focused on the fundamental principle that humans in social situations choose behaviors that maximize their likelihood of meeting self-interests in those situations. Descriptive and explanatory research designs were utilized in this study and the following networks were sampled; Safaricom, Airtel, Orange and, yuMobile A questionnaire was used to collect data from sample size of 250 respondents who were sampled from the staff of public universities in the Western region which included Moi, Masinde Muliro, Maseno, Jaramogi Oginga Odinga, University of Eldoret and Kisii University. Data collected was analyzed by use of descriptive and inferential statistics. Multiple regressions were used to establish the effect between customer relationship management practices, customer satisfaction and customer Retention. The results revealed that Perceived value had significant effect on Customer satisfaction. Also, it was established that, Customer satisfaction was significant in predicting customer retention. The study recommends that service providers should put more emphasis on Customer Relationship Management Practices since they influence customer satisfaction and hence customer retention. The study provides new theoretical insight into factors influencing customer retention by incorporating customer satisfaction as a mediator in the relationship between Customer Relationship Management Practices and customer retention.
\end{abstract}

Keywords: Customer satisfaction, Perceived Value, relationship, retention, customer relationship management practices

\section{Background Information}

Organizations both private and public in today's dynamic market place are increasingly leaving anticipated marketing philosophies and strategies to the adoption of more customer-driven initiatives that seeks to understand, attract, retain and build long term relationship with profitable customers (Kotler, 2006, Gronroos, C 1994). Therefore, as the competitive business environment becomes more turbulent, the most important issue the sellers face is no longer to provide quality products or services, but keep loyal customers who will contribute long-term profit to organizations (Tseng, 2007). Bateson and Hoffman (2002), define customer retention as focusing a firm's marketing effort towards the existing customer's base.

Many firms recognize the importance of customer's satisfaction but relatively few understand the economics of customer satisfaction within their own firms. It is claimed that $5 \%$ improvement in customer retention can cause an increase in profitability of between 25 and 85 percent depending on the industry (Kerin, Hartley, \&Rudelius, 2009; Reichheld \& Sasser, 1990). CRM practices is defined as, 'activities that focuses on managing the relationship between a firm and its current and prospective customer base, as a key to success, (Gebert, 2003). It further, means developing a comprehensive picture of customer needs, expectations and behaviors and managing those factors to affect business performance. CRM practices help in building long lasting relationships and these relationships give a company joy of retained customers.

In service studies, customer satisfaction is the customers' state of emotion after experiencing the service (Baker and Crompton, 2000; Sanchez et al., 2006). Customer satisfaction is the extent of overall enjoyment that customer feel, the result that the service experience able to fulfill the customer desires, expectation, needs and wants from the service (Chen and Tsai, 2007). Taylor et al., (2004) pointed out that customer satisfaction has a direct influence on customer loyalty. Kotler (2008) describes customer satisfaction is the feeling of happiness or unhappiness as a result of comparing the perceived performance of services or products with the expected performance. If the perceived performance does not meet the expected performance, then the customer will feel disappointed or dissatisfied. Homburg et al. (2008) suggested that customer satisfaction has been a crucial issue in marketing field in the past decades since satisfied customers are able 
to offer to the company such as customer loyalty and continuous profitability. The demand for mobile phones in Kenya in the last few years has been more than most people expected and continues to expand. According to the Communications Commission of Kenya (CCK), mobile phone usage in Kenya has grown to an average of 65 percent a year for the past five years. This is twice the rate of growth in Asian countries. In Kenya, the growth rate is even higher. Statistics indicate that Kenya has more than 18 million subscribers, up from 6.5million in the year 2006 (Nokia, 2010). Penetration of mobile telephone in Kenya, like many other developing countries, is mainly driven by affordability and innovation.

\section{Literature Review}

\subsection{Concept of Customer Satisfaction}

Customer satisfaction is perceived as a relative judgment that considers the qualities versus the cost and efforts obtained through a purchase (Ostrom and Lacobucci, 1995). Customer satisfaction is considered as important outcome of a buyer-seller interaction (Rooset al.., 2006; Smith and Barclay, 1997). The literature contains two general conceptualizations of customer satisfaction: transaction-specific satisfaction and cumulative satisfaction (Bolton and Drew, 1991; Cronin and Taylor, 1994; Shankar et al., 2003). While transaction-specific satisfaction may provide specific diagnostic information regarding a specific product or service encounter, cumulative satisfaction resulting from a series of transactions or service encounter is a more fundamental indicator of a firm's past, current and future performance (Anderson et al., 1997; Lam et al., 2004; Oliver,1997). Therefore, this study focuses on cumulative satisfaction and defines satisfaction as the emotional state developed from a relationship that resulted from customer interactions over time.

The notion of customer satisfaction is part of a wider focus on building total customer value, which can be defined as: 'the perceived monetary value of the bundle of economic, functional and psychological benefits customers expect from a given market offering' (Kotler and Keller, 2009). Zeithaml and Bitner (2000), define customer satisfaction as follows: 'Satisfaction is the customer evaluation of a product or service in terms of whether that product or service has met their needs and expectations.

Customer satisfaction has been fundamental to the marketing concept for over three decades (Parker and Mathews, 2001). It is widely recognized in the good and service sectors that customer satisfaction as the main performance indicator and the key to success for any business organization (Mihelis, Grigoroudis, Siskos, Politis, and Malandrakis, 2001). However, the intangible nature of customer satisfaction makes the term hard to measure. Therefore, many researchers attempt to discover the antecedents and consequences of customer satisfaction in order to provide a better understanding of customer, increase market share and profitability, reduce cost and enhance product or service performance as well as internal quality control (Anderson and Sullivan, 1993; Ndubisi and Chan, 2005). Sprowls and Asimow (1962) contrasted and discussed customer behavior model and reported that customer satisfaction result in repeated purchase and emphasize the importance of customer satisfaction for the organization. In early 1970s, Anderson (1973) and Olshavask and Miller (1972) investigated customer satisfaction based on the expectation and perceived product performance. Churchill and Suprenant (1982) study identify the antecedent and construct measurement of customer satisfaction based on disconfirmation paradigm. Previous studies define customer satisfaction as 'disconfirmation paradigm' (Churchill and Suprenant, 1982), which is a result of confirmation/disconfirmation of expectations that compare product (or service) performance with their expectations and desire (Spreng, MacKenzie, and Olshavsky, 1996). Boulding, Kalra, Staelin, and Zeithaml (1993) conceptualized customer satisfaction into transaction specific and cumulative (Anderson, Fornell and Lehmann, 1994). The transaction specific viewed customer satisfaction as evaluative judgement after a specific buying process (Hunt 1977; Oliver, 1993). However, cumulative customers' satisfaction emphasizes more on the total evaluation based on total consumption over time (Johnson and Fornell 1991; Fornell 1992). Other researchers consider the term customer satisfaction as an attitude or evaluation formed by customers who compares pre-purchase expectations about the outcome of a product or service from the actual performance they received (Oliver, 1980; Fornell, 1992).

According to Hoyer and MaClnnis (1997), consumers measure their experiences of a product or service after acquisition, consumption and disposition. Customer satisfaction / dissatisfaction require experience with the product which depends on the quality and value of the service (Anderson et al., 1994). Any discrepancy may cause disconfirmation (Hoyer et al, 997), thus, failure to meet the needs and expectations is assumed to result in dissatisfaction with the product or service'. Hoyer and MaClnnis (1997), argued that a favourable outcome means they are satisfied whilst an unfavourable outcome results in dissatisfaction. The conceptual relationship between customer satisfaction and service quality has generated mixed results among researchers. Anderson et al. (1994) points out a distinction between customer satisfaction and future experience a customer gets when he comes into contact with a product or service and value received. Recent studies have also pointed out that service quality is an antecedent of customer satisfaction (Anderson and Sullivan, 1993; Cronin and Taylor, 1992). There is however, consensus that further studies would have to be done on this issue. Satisfaction is based on the customer's previous experiences with the service provider, advice of friends and associates, competitors offering and information from marketers (Kotler, 1997). It has also been argued that satisfaction/dissatisfaction with a product or pleasure will lead to satisfaction. In contrast, negative emotions such as grief, sadness, distress, sorrow, regret, disappointment, anger, agitation, will engender dissatisfaction (Zeithaml and Bitner, 2000; Hoyer and MaClnnis, 1997). Services are influenced by customers' state of mind and emotions, even Positive feelings such as happiness, excitement.

Customers stay longer in consuming company services due to a developed sense of security and loyalty brought about by the satisfaction and they deepen their relationship with the company. Customers will also demonstrate less price sensitivity, due to the fact that the products and services provided exceed the customers' expectations and thus raising the 
individual switching costs. Customers tell and recommend company product or service. Satisfied customers tend to tell others of the benefits of the products and services received, thus marketing the organizations products and services. Theoretically, service attributes can be considered as a cognition-based construct, while customer satisfaction is mainly an effective and evaluative response (Oliver, 1993).

Social science literature indicates that cognitive thought processes trigger affective responses (Weiner, 1996), suggesting that customer assessments of service attributes affect their satisfaction attitude. That is, the degree to which suppliers could meet the requirements of customers influenced the strength of the customers' positive attitude toward the service providers (Turnbull and Moustakatos, 1996). Customer satisfaction is a complex construct and has been defined in various ways (Besterfield, 1994; Barsky, 1995; Kanji and Moura, 2002; Fecikova, 2004). Recently, researchers have argued that there is a distinction between customer satisfactions as related to service experiences. The distinction is due to the inherent intangibility and perishability of services, as well as the inability to separate production and consumption. Hence, customer satisfaction with services and with goods may derive from, and may be influenced by, different factors and therefore should be treated as separate and distinct (Veloutsouet al, 2005).

Research has shown that it cost between five to six times more to attract a new customer than to keep an existing customer. Companies can also boost profits anywhere from $25 \%$ to $125 \%$ by retaining merely $5 \%$ more existing customer and also that happy customers will tell to others of their positive experience, whereas dissatisfied customers tell 9 to 12 how bad it was. It is also assumed that only one out of 25 dissatisfied customers will express dissatisfaction and two third of customers do not feel valued by those serving them. (Adapted from Gary Luck, The Ash ridge journal, Customer Satisfaction Strategy, autumn (2006).

The customers will have expectations that relate to the company branches and offices that they visit their staff and deal with the organization as all customers' needs and wants change over time and thus the organization seeking to satisfy these needs has to be dynamic and responsive to the customer's expectations. Schneider and Bowen (1995) assert that 'service organizations must meet three key customer needs to deliver service excellence,' Security, esteem and justice. They also identified an array of service quality factors that are important for customers including timeliness and convenience, personal attention, reliability and dependability, employee competence and professionalism, empathy, responsiveness, assurance, and availability and tangibles such as physical facilities and equipment and the appearance of personnel.

Customer satisfaction holds the potential for increasing the organizations customer base, increase the use of more volatile customer mix and increase the firm's reputation, (Fornell1992, Levesque and Mc Daugall, 1999). This means that firms in the mobile industry should satisfy their customers so that they can become loyal and remain with them. Marketing theory and practice suggest that mobile phone firms should improve their service by satisfying their customers, so as to obtain and sustain advantage in the intensely competitive business environment. This is because the main output of customer satisfaction is customer loyalty, and a firm with bigger share of loyal customers, profit from increased repurchase rate, greater cross buying potential, higher price willingness, positive recommendation behavior and lower switching tendencies. Furthermore, long term customers tend to take less of company time and are sometimes less sensitive to the price, Ganet al (2006). They further indicate that retaining customers become the priority for most enterprises and there are compelling arguments for managers to carefully consider the factors that might increase customer retention rate. In any case, the cost of creating a new customer has been estimated to be five times the cost of retaining existing customers, (Reichheld 1996). A retained customer will always show resistance to competitors' enticement and will be able to give both solicited and unsolicited referral (Omotayoet al, 2008). Customer retention is, therefore, crucial to mobile cellular companies; because improvement in customer retention can cause an increase in profitability; depending upon the industry (Reichheld and Sasser, 1990). The mobile telephone industry has undergone rapid changes in the recent years. The deregulation of the industry has caused a lot of service providers to enter the industry hence increasing the competition in the industry. The competition in the industry can be described as fierce and stiff.

The cellular phone companies are, therefore, doing everything possible to attract new customers and retain the existing ones. Service quality has, therefore, become very crucial for the service providers in the retention of their customers. In recent times, subscribers have complained vehemently on the quality of services provided by service providers. A substantial number of customers of mobile telephones have taken service providers to task for rendering unsatisfactory services. However, there is little empirical research undertaken, as far as can be ascertained on how quality service leads to customer retention in the mobile telephony industry. The study aims at investigating whether a service provider in general is doing what customers perceive as quality service to improve customer retention. The study is undertaken to clarify certain questions related to customer retention in the mobile telephone Industry.

\subsection{Social Exchange Theory}

The theory attempts to explain the nature of the relationships between Customer relationship management practices, Customer satisfaction and Customer Retention. The theoretical model adopted for this study was derived from the social exchange theory (Homans, 1958), which posits that all human relationships are formed by the use of cost-benefit analysis and comparisons of alternatives. Homans suggested that when an individual perceives the cost of a relationship outweighs the perceived benefits, then the person will choose to leave the relationship. The theory further states that persons that give much to others try to get much from them, and persons that get much from others are under pressure to give much to them.

The social exchange relationships between two parties develop through a series of mutual exchanges that yield a pattern of reciprocal obligations to each party. Social exchange theory indicates that individuals are willing to maintain 
relationships because of the expectation that to do so will be rewarding. Individuals voluntarily sacrifice their self- benefits and contribute these benefits to other individuals with the expectation for more future gains. Thibaut and Kelly (1959) propose that whether an individual retains a relationship with another one depends on the comparison of current relationship, past experience and potential alternatives. The constant comparison of social and economic outcomes between a series of interactions with current partners and available alternatives determines the degree of an individual's commitment to the current relationship.

The theory is appropriate for this study because service encounters can be viewed as social exchanges with the interaction between service provider and customer being a crucial component of satisfaction and providing a strong reason for continuing a relationship (Barnes, 2007). Social exchange theory attempts to account for the development, growth and even dissolution of social as well as business relationships. In other words, people (or business firms) evaluate their reward - cost ratio when deciding whether or not to maintain a relationship. Rewards and costs have been defined in terms of interpersonal (e.g., liking, familiarity, influence), personal (gratification linked to self esteem, ego, personality) and situational factors (aspects of the psychological environment such as a relationship formed to accomplish some task). In a services context, considering the level of interpersonal contact needed to produce services, there is a range of psychological, relational and financial considerations that might act as a disincentive for a hypothetic change of service providers. In the late 1960s and early 1970s, exchange theory began to play a major role in family studies. Scholars pointed out how exchange theory could be applied to a variety of family issues such as mate selection, courtship, sexual bargaining, marital quality, marital power, family violence, and many others at both the micro- and macro-levels.

\subsection{Perceived Value and Customer Satisfaction}

Perceived value has its root in equity theory, which considers the ratio of the consumer's outcome/input to that of the service provider's out- come/input (Oliver and DeSarbo, 1988). The equity concept refers to customer evaluation of what is fair, right, or deserved for the perceived cost of the offering (Bolton and Lemon, 1999). Perceived costs include monetary payments and non-monetary sacrifices such as time consumption, energy consumption, and stress experienced by consumers. In turn, customer-perceived value results from an evaluation of the relative rewards and sacrifices associated with the offering. Customers are inclined to feel equitably treated if they perceive that the ratio of their outcome to inputs is comparable to the ratio of outcome to inputs experienced by the company (Oliver and DeSarbo, 1988). And customers often measure a company's ratio of outcome to inputs by making comparisons with its competitors' offerings. Customer value is 'the fundamental basis for all marketing activity' (Holbrook, 1994, p. 22). And high value is one primary motivation for customer patronage. In this regard, Sirdeshmukh, Singh, and Sabol (2002) argue that customer value is a superordinate goal and customer loyalty is a subordinate goal, as it is a behavioral intention. According to goal and action identity theories, a superordinate goal is likely to regulate subordinate goals. Thus, customer value regulates 'behavioral intentions of loyalty toward the service provider as long as such relational exchanges provide superior value' (Sirdeshmukhet al., 2002, p.21).Prior empirical research has identified perceived value as a major determinant of customer loyalty in such settings as telephone services (Bolton and Drew,1991), airline travel and retailing services (Sirdeshmukhet al., 2002).Chang and Wildt (1994) report that customer-perceived value has been found to be a major contributor to purchase intention.

\section{Research Methodology}

\subsection{Research Philosophy}

In this study positivism was chosen more than phenomenological perspective because we believe that customer retention as pertaining mobile phone service users can be defined objectively through the use of established theoretical frameworks and structured instruments to assess and analyze it, upon which generalizations can be made from the finding

\subsection{Research Purpose}

The research purpose is abroad statement of what the research hopes to achieve. According to purpose, research could be broadly divided into exploratory, descriptive and explanatory (Saunders et al 2000, 2007; Cooper and Schindler 2006). An explanatory research is a study that is conducted to 'find out what is happening, to seek new insights, to ask questions and to assess phenomena in a new light' (Robson2002:59). It is mainly used when a researcher wants to have a clearer understanding of a situation or a problem, where the area of study is so new or vague, important variable may be known or defined. It therefore uses such methods as searching documented materials, asking for expert's opinion, and conducting a focus group interviews.

This study had significant combination of both the two: Descriptive and explanatory purposes. Firstly, the study sought to better understand those CRM Practices that customers are satisfied or dissatisfied with, so it was descriptive. Secondly, the study sought to determine the effect of CRM Practices on customer retention and to examine its relationship therefore it was explanatory.

\subsection{Research Approach}

This study selected existing empirical theories and models, applying and testing them in measuring customer satisfaction in the context of the mobile phone users in Kenya. Therefore, this study is deductive. 


\subsection{Time Horizon}

This study chose a cross-sectional study because data was collected from a cross section of Mobile phone service users once and not for different periods of time.

\subsection{Research Strategy}

Research Strategy is a general plan of how to answer the research questions. It is mainly guided by the research questions and research objectives, among other things. It determines to a large extent the choice of data collection methods. This study chose basically the survey strategy because it sought the opinion of a population about a specific subject matter and it combined the use of qualitative and quantitative methods

\subsection{Target Population}

The target population for the study was the users of Mobile Phone services and enjoying the use of Customer Relationship Management practices. Burns and Groove (1997) argues that a target population is the entire aggregation of respondents that meets designated set of criteria. The Target population of the study consisted of staff in public universities' in Western Kenya Region. The study defined Western Kenya as the region covering North Rift, former Nyanza province and former Western province. The public universities in the Western region included Moi, MasindeMuliro, Maseno, JaramogiOgingaOdinga, University of Eldoret, Kisii University as at June, 2014. The staff in these Universities was characterized by grade, gender, working experience, level of education, and level of mobile phone exposure. The study targeted a population of 15007 which was indicated in official records in the payrolls of respective universities. The following is how the 15007 was arrived as a target population for this study;

\begin{tabular}{|c|c|}
\hline Strata & Target Population \\
\hline Moi University & 6,900 \\
\hline Maseno University & 2,500 \\
\hline MasindeMuliro University of Science and Tech. & 1,400 \\
\hline JaramogiOgingaOdinga University & 2,070 \\
\hline Kisii University & 837 \\
\hline University of Eldoret & 1300 \\
\hline Total & 15007 \\
\hline Table 1: Target Population \\
Source: Survey Data
\end{tabular}

\subsection{Sampling Technique}

In selecting the sample of 250 respondents, a stratified simple random sampling was used. This technique was chosen because the population consisted of mobile phone users in each stratum. Stratified random sampling ensures greater representiveness across the entire population and also results in a smaller sampling error, giving greater precision in estimation (Wegner, 2000).

\subsection{Sample Size}

The sample size of each stratum in stratified random technique will be proportionate to the population size of the stratum when viewed against the entire population. This means that each stratum (each University) has the same sampling fraction (Castillo, 2009). The simple random sampling or probability sampling was used so that each and every one in the target population had an equal chance of inclusion. The sample size of Universities in each stratum and the number of respondents was obtained using coefficient of variation. Nassiuma (2000) asserts that in most surveys or experiments, a coefficient of variation in the range of $21 \%$ to $30 \%$ and a standard error in the range $2 \%$ to $5 \%$ is usually acceptable. The Nassiuma's formula does not assume any probability distribution and is a stable measure of variability. Therefore, a coefficient variation of $30 \%$ and a standard error of $2 \%$ were used in this study. The upper limit for coefficient of variation and standard error will be selected so as to ensure low variability in the sample and minimize the degree or error.

The formula will be;

$\mathrm{S}=\quad \underline{\mathrm{N}(\mathrm{CV})^{2}}$

$(\mathrm{CV})^{2}+\overline{(\mathrm{N}-1) \mathrm{e}^{2}}$

where $\mathrm{S}=$ the sample size

$\mathrm{N}=$ the population size

$\mathrm{Cv}=$ the Coefficient of Variation

$\mathrm{e}=$ standard error

Therefore, the sample size of Universities will be as indicated in the table below;

$=\underline{15007\left(0.3^{2}\right)}=250$

$0.3^{2+} 15007-(0.02)^{2}$ 


\begin{tabular}{|c|c|c|}
\hline Name of University & Total Population & Sample Size \\
\hline Moi University & 6,900 & 102 \\
\hline Maseno University & 2,500 & 36 \\
\hline MasindeMuliro University of Science and Tech. & 1,400 & 20 \\
\hline JaramogiOgingaOdinga University & 2,070 & 30 \\
\hline Kisii University & 837 & 13 \\
\hline University of Eldoret & 1300 & 20 \\
\hline Total & 15007 & 250 \\
\hline
\end{tabular}

Table 2: Sampling Frame of the Public Universities in Western Kenya Region

Source: Survey Data, 2014

\subsection{Data Collection Instrument}

The questionnaire was used as the data collection instruments to enable achieve the stated objectives. The instrument was appropriate as it helped in collecting the primary data. The questionnaire was designed based on the fivepoint Likert-type scales. This was so because it was to enable answer specific research questions and help achieve the objectives of the study. Closed ended questions were used as they were deemed to motivate the respondents and save time.

\subsection{Measures of Reliability and Validity}

Saunders et al 2000; cooper and Schindler 2006; and Malhotra N. K and Birks D. F. 2007 agree that in any research, it is expedient as a matter of reliability and validity check that the questionnaire should be pre-tested before final administration. The measurement scale in the questionnaire were deemed to have content and construct validity because they reflect the key components of CRM practices, Customer satisfaction and customer retention described in the literature.

\subsection{Reliability of Study Measures}

Reliability refers to whether a measurement instrument is able to yield consistent results each time it is applied. In order to test for reliability, Cronbach alpha coefficient was used since was the common method used for assessing reliability for a measurement scale with multi-point items. The reliability of the study measures was assessed by Cronbach's Alpha coefficient, which was used to assess the internal consistency or homogeneity among the research instrument items (Sekaran, 1992). The coefficient that reflects homogeneity among a set of items varies from 0 to 1 . A good reliability should produce at least a coefficient value of 0.70 (Hair et al., 1995) but coefficients up to 0.62 are acceptable in social research studies (Kritsonis and Hurton, 2008). For this research the reliability coefficients met the criteria since all the reliability coefficients of the study variables were above 0.7 . The concepts of validity and reliability require the researcher to ensure data is gathered and treated in a manner that will not include change to interpretation. This means there is need to record the problem of the study as closely as possible (Creswell, 2003). However, there is no absolute reliability in undertaking a research. The use of questionnaires is one source of bias because of literacy problems which may be present in the target respondents.

\subsection{Validity}

Validity refers to whether the statistical instrument measure what it is intended to measure, i.e., accuracy of measurement (Sullivan T.J. 2001; Saunders et al., 2000;2007). Validity is concerned with whether the findings are really what they appear to be about. This study will address the four approaches to establishing validity; face validity, content validity, criterion validity and construct validity (Zikmundet al., 2010). Face validity was established by inspecting the contents being studied for their appropriateness to logically appear to reflect what was to be measured further, face validity involves assessing whether a logical relationship exist between the variables and the proposed measure.

To establish content validity this research was validated by determining the variables which have been defined and used in literature previously. Additionally, opinions from experts were sought to provide relevant inputs adding to what had been identified from the literature. Piloting a questionnaire was crucial and had highlighted ambiguities and other potential pitfalls (Somekh and Lewin, 2005). The pilot study was carried out in Egerton University. Feedback from the pilot study enabled the researcher to make changes where necessary to the questionnaire. In addition, the respondents may have experienced boredom because the questions may seem monotonous and towards the end of the questionnaire, the respondent may not pay keen attention to details of the question. Yet another bias that may be experienced in the course of this research is acquiescence. This issue may arise when the respondent tends to agree with an issue whenever they are not sure or undecided. To overcome this possible bias, the study was to provide a short questionnaire. Reliability test was performed on the questionnaire items using Cronbach alpha. However, the threshold that is acceptable in closely related researches is 0.7 and this is what will be the guide to this study (Eisenmergeret al, 1986).

\subsection{Data Analysis and Presentation}

To establish the main characteristics of the study variables, descriptive statistics, factor analysis using principal component method with varimax rotation and Pearson correlations analysis was done and relevant tests conducted. To establish the statistical significance of the respective hypotheses, ANOVA of F-tests as well as multiple linear regression analysis was conducted, appropriate at 95 percent confidence level $(\alpha=0.05)$. The questionnaire returned from the field 
was coded, edited and keyed into the computer to facilitate statistical analysis. Statistical package for social sciences (SPSS) version 17 was used to assist in analysis. Analyzed data was interpreted and presented in tables.

Data analysis was undertaken using multiple regressions to examine the way a number of independent variables relate to one dependent variable. Multiple regression was used as a technique to analyze continuous variable (Steel and Ovalle, 1984). Baron and Kenny $(1986,2003)$ four steps were also used to test mediation; the SOBEL Test was also used to test the magnitude of confidence among the variables. The dependent variable is assumed to be a linear function as;

Model: effects of CRM Practices on Customer Satisfaction

$\mathrm{CS}=\beta_{0}+\beta_{2} \mathrm{PV}+\mathrm{e}$,

Where;

CS= Customer Satisfaction; $\beta_{\mathrm{o}}=\mathrm{a}$ constant; $\beta_{2}$ = beta values; CRM Practices (PV - perceived value); e - Error term

\section{Data Analysis, Presentation and Interpretation}

\subsection{Response Rate}

The study intended to collect data from 250 respondents, but data was successfully collected from 222 respondents. This represents a response rate of 88.8 percent of the target population, which falls within the confines of a large sample size (Anderson, Sweeney and Williams, 2003)

\subsection{Profile of the Respondents}

The respondents' profiles of interest in this study were; Gender, Age of respondent, highest level of education, mobile phone service provider, and service provider used most and lengthy of time of usage of the services.

The total sample for the survey consists of 222 respondents. The gender distribution of the survey respondents is 65.3 per cent males and 34.7 per cent females. The results also indicated that the samples have age predominantly of 45 years and above, which is 46.4 per cent. More than 50 per cent of the respondents use Safaricom mobile phone service provider. Majority of the respondents have college or higher education level where 10.4 per cent are professional qualification, 13.5 per cent are diploma or advanced diploma holder, 16.2 per cent have degrees and 53.2 per cent have postgraduate level of education. Only 6.8 per cent of respondents have attained high-school level. The results are presented in Table 3.

\begin{tabular}{|c|c|c|c|}
\hline Variables & & Frequency & Percentage \\
\hline Gender & Male & 145 & 65.3 \\
& Female & 77 & 34.7 \\
\hline Age & $18-24$ & 20 & 9.0 \\
& $25-34$ & 18 & 8.1 \\
& $35-44$ & 81 & 46.5 \\
\hline Level of Education & 45 and above & 103 & 6.8 \\
& O-Level & 23 & 10.4 \\
& Certificate & 30 & 13.5 \\
& Diploma & 36 & 53.2 \\
\hline Mobile Service Provider & Bachelor's Degree & 118 & 50 \\
& Post Graduate Degree & 111 & 36 \\
& Safaricom & 80 & 12.6 \\
& Airtel & 28 & 1.4 \\
\hline Mobile Service Provider used often & Orange & 3 & 46.8 \\
& Yu-mobile & 104 & 30.6 \\
& Safaricom & 68 & 16.7 \\
\hline Period of Usage & Airtel & 37 & 5.9 \\
\hline & Orange & 13 & 8.1 \\
\hline
\end{tabular}

Table 3: Demographic Profile of Respondents Source: Research Data (2014)

\subsection{Descriptive Statistics}

For clear determination of the responses made to the research items, the mean, standard deviation, skewness and kurtosis of the study variables were determined as highlighted in Table 4

\begin{tabular}{|c|c|c|c|c|}
\hline Variables & Mean & Std dev & Skewness & Kurtosis \\
\hline PV & 3.0748 & 0.76270 & -0.353 & 0.629 \\
\hline CS & 3.4234 & 0.79292 & -0.583 & -0.248 \\
\hline \multicolumn{4}{|r|}{ PV=Perceived Value, CS=Customer Satisfaction } \\
\hline
\end{tabular}


From Table 4 Perceived Value have a mean score of 3.0748 and a standard deviation of 0.76270 , its skewness and kurtosis are -0.353 and 0.629 respectively making it skewed to the right side of the curve. Customer satisfaction is the mediator which has a mean of 3.4234 and a standard deviation of 0.79292 , its skewedness is -0.583 and its peakedness of 0.248 .

\subsection{Scale Reliability of Study Variables}

The reliability of an instrument is defined as its ability to consistently measure the phenomenon it is designed to measure. The reliability of the questionnaire was therefore tested using Cronbach alpha measurements. From the table 5

\begin{tabular}{|c|c|c|}
\hline Variables & Number of Items & Cronbach Alpha Coefficient \\
\hline $\mathrm{PV}$ & $\mathbf{5}$ & 0.808 \\
\hline $\mathrm{CS}$ & $\mathbf{4}$ & 0.722 \\
\hline \multicolumn{2}{|c|}{$\mathrm{PV}=$ Perceived Value, CS=Customer Satisfaction } \\
\hline \multicolumn{2}{|c|}{ Table 5: Cronbach's Alpha Reliability } \\
Source: Research Data (2014)
\end{tabular}

The reliability coefficients (a) of each variable are as follows: Perceived Value (0.808); Customer satisfaction (0.722) and Customer retention (0.716). The reliability coefficients of most of the variables are above 0.70 , which concurs with the suggestion made by Nunnally (1978). The internal consistency was considered to be sufficient and adequate. As indicated in the above table Cronbach's alpha was computed separately for the study variables to enable assess the internal consistent among the study variable.

\subsubsection{Factor Analysis}

Factor analysis was conducted to create variable composites from the original attributes and to identify a smaller set of factors that explain most of the variances between attributes. Factor analysis was done on Network Quality, Perceived Value, and Customer Relational Experiences, Loyalty Programs, Image, Customer Satisfaction and Customer Retention.

\subsubsection{Factor Analysis Results of Perceived Value}

The Kaiser Criterion was used to determine the number of factors to extract for analysis. Results show that the 5 items for Perceived Value are sorted and clustered into one component. The Kaiser-Meyer-Olkin (KMO) measure of sampling adequacy and Barlett's Test of Sphericity were used. The KMO measure of sampling adequacy indicated a value of $(\mathrm{KMO}=0.767)$ indicating that the sample size was adequate for the variables entered into analysis. The Barlett's Test of Sphericity was significant $\mathrm{X}^{2}=418.074, \mathrm{df}=10, \mathrm{p}<0.000$, implying that the factor analysis was appropriate for the study and there was relationship among variables for the Perceived Value. From Table 6, the results of the principal component analysis indicate that, there is one factor whose Eigenvalues exceed 1. The Eigenvalue of a factor represents the amount of total variance explained by that factor. For Perceived Value, the first factor has Eigenvalue of 2.918 which explain $58.352 \%$ of the total variance, the percentage of variance combines for the succeeding items to make up 100\% variance. Varimax rotation tries to maximize the variance of each of the factor, so the total amount of variance accounted for the redistribution over the extracted factor. Principal component analysis with varimax rotation is widely adopted as a reliable method of factor analysis (Lee, 2010).

\begin{tabular}{|c|c|}
\hline Scale Item & Factor Loadings \\
\hline Good Value for money & 1 \\
\hline Value ease of use & .839 \\
\hline Convenience of using service provider & .811 \\
\hline Overall ability to give up High & .783 \\
\hline Convenience of using service provider & .812 \\
\hline Overall ability to give up High & .783 \\
\hline Over ability is high & .812 \\
\hline Notes: Eigenvalues & 2.918 \\
\hline Percentage of Variance & $58.352 \%$ \\
\hline Approx. Chi-Square 418.074, Df 10, Sig. .000 & \\
\hline Extraction Method: Principal component Analysis \\
Rotation Method: Varimax with Kaiser Normalization \\
\hline Rotation converged in 3 iterations \\
\hline
\end{tabular}

Table 6: Perceived Value Component Matrix

Source: Research Data (2014)

\subsubsection{Factor Analysis Results of Customer Satisfaction}

The Kaiser-Meyer-Olkin (KMO) measure of sampling adequacy and Barlett's Test of Sphericity were used. The KMO measure of sampling adequacy indicated a value of $(\mathrm{KMO}=0.594)$ indicating that the sample size was adequate for the variables entered into analysis. The Barlett's Test of Sphericity was significant $X^{2}=307.448, d f=6, p<0.000$, implying that 
the factor analysis was appropriate for the study and there was relationship among variables. The results of the principal component analysis indicate that, there are two factors whose Eigenvalues exceed 1. The Eigenvalue of a factor represents the amount of total variance explained by that factor. For Customer satisfaction, the first factor has Eigenvalue of 2.231 and explain 55.768\% of the total variance and the second factor has Eigenvalue of 1.148 and explain 28.697, the two factors explain $84.464 \%$ of the total variance. The first factor explains $55.768 \%$ of this variance, while the second variable explained $28.697 \%$ of this variance. Varimax rotation tries to maximize the variance of each of the factor, so the total amount of variance accounted for the redistribution over the extracted factor. Principal component analysis with varimax rotation is widely adopted as a reliable method of factor analysis (Sinkkonnen, Malhotra and Galleta, 1999).

\begin{tabular}{|c|c|c|}
\hline Scale Item & & Factor Loadings \\
\hline & 1 & 2 \\
\hline Satisfied with this service provider's services & .909 & \\
\hline Service provider is successful & & .707 \\
\hline Service provider meets my expectations & .870 & \\
\hline Overall, service provider has met my expectations & .952 & \\
\hline $\begin{array}{c}\text { Notes: Eigenvalues } \\
\text { Percentage of Variance } \\
\text { of sampling adequacy .729 } \\
\text { Approx. Chi-Square 307.448, Df 6, Sig. .000 }\end{array}$ & $\begin{array}{c}2.231 \\
55.768 \%\end{array}$ & $\begin{array}{c}1.148 \\
28.697 \%\end{array}$ \\
\hline \multicolumn{3}{|c|}{$\begin{array}{c}\text { Extraction Method: Principal component Analysis } \\
\text { Rotation Method: Varimax with Kaiser Normalization } \\
\text { Rotation converged in } 3 \text { iterations }\end{array}$} \\
\hline
\end{tabular}

Table 7: Customer Satisfaction Rotated Component Matrix Source: Research Data (2014)

\subsection{Correlation Analysis}

The correlation shown in the table below presents bivariate correlations between variables. Since a single construct in the questionnaire was measured by multiple items, the average score of the multi-items for a construct was computed and used in further analysis such as correlation analysis and multiple regression analysis (Wang and Benbasat, 2007).

From the table attached, When the correlation coefficient value (r) ranges from $0.10-0.29$, is considered to be weak, 0.30-0.49, medium, 0.5-1.0 is considered strong, Wong \&Hiew (2005). According to Field (2005), correlation coefficient should not go beyond 0.8 to avoid Multicollinearity. In this research, the highest correlation coefficient is 0.69 , thereby implying that there was no multicollinearity problem in this research, since the value is less than 0.8 . PV is positively and statistically significant $(\mathrm{r}=0.541, \mathrm{p}<0.00$ (2 tailed at $1 \%$ level of significance), CS is positively and statistically significant, $(\mathrm{r}=0.434, \mathrm{p}<0.00$ (2 tailed at $1 \%$ level of significance), The PV, were correlated to customer retention and were positively and statistically significant.

\begin{tabular}{|c|c|c|c|c|c|c|c|}
\hline & NQ & PV & CRE & LP & CS & CR & Sig. (2 tailed) \\
\hline NQ & 1 & & & & & & \\
\hline PV & .516 & 1 & & & & & \\
\hline CRE & .707 & .790 & 1 & & & \\
\hline LP & .723 & .542 & .673 & 1 & & \\
\hline CS & .434 & .214 & .524 & .518 & 1 & & \\
\hline CR & .501 & .461 & .512 & .587 & .646 & 1 & \\
\hline \multicolumn{7}{|l}{ NQ= retwork Quality, PV=Perceived Value, CRE=Customer Relational Experience, LP=Loyalty Programs, } \\
CS=Customer Satisfaction and CR=Customer Retention
\end{tabular}

Table 8: Pearson Correlation Coefficient of Study Variable

Source: Research Data (2014)

\section{Summary of Findings, Conclusions and Recommendations}

\subsection{Summary of Findings}

The study examined the mediating effect of customer satisfaction on the relationship between customer relationship management practices on customer retention among mobile phone users in public universities of western Kenya region. The study was guided by the following objective to determine the effect of Perceived Value on Customer Satisfaction,perceived Value has no significant effect on customer retention. From the findings, it was found that Beta coefficients (Perceived Value), $\mathrm{B}=-0.637, \mathrm{t}=-2.866, \mathrm{p}=0.005$. The Null hypothesis was therefore rejected since its $\mathrm{p}$-value is $<0.05$ and an alternative hypothesis were accepted, meaning that there is an effect of Perceived Value on customer retention. This result supports prior researches that Perceived Value has its root in equity theory, which considers the ratio of the consumer's outcome/input to that of the service provider's out- come/input (Oliver and DeSarbo, 1988). Again from, customer-perceived value results from an evaluation of the relative rewards and sacrifices associated with the offering. Customers are inclined to feel equitably treated if they perceive that the ratio of their outcome to inputs is 
comparable to the ratio of outcome to inputs experienced by the company (Oliver and DeSarbo, 1988). (Holbrook, 1994, p. 22), argues that, Customer value is 'the fundamental basis for all marketing activity' And high value is one primary motivation for customer patronage hence retention. In this regard the findings of this study are supported by, Sirdeshmukh, Singh, and Sabol (2002), who argued that customer value is a superordinate goal and customer loyalty is a subordinate goal, as it is a behavioral intention and this enhances retention.

\subsection{Conclusions}

Results of this study provided support for the Hypotheses linking CRM practices, customer satisfaction and customer Retention. The concept and its roots were introduced by reviewing the existing academic literature, as the competitive environment becomes more turbulent, the most important issue the sellers face is no longer to provide excellent, good quality products or services, but also to keep loyal customers who will contribute long-term profit to organizations (Tseng, 2007).

This study identified the number of customers, or percentage of total customers whose experience with their telecommunication service provider's products or services meets or exceeds their expectations. In a competitive market place where businesses compete for customers, customer satisfaction is seen as a key differentiator and increasingly has become a key element of business strategy. According to the study, Customer satisfaction is about how products and services meets consumer's needs. It is the impression of customers about services provided

The recommendations will act as eye opener to both the academicians and practitioners in marketing and help in filling the gap in the context of the mediation effect of Customer satisfaction on the relationship between CRM practices (Perceived Value) and Customer satisfaction.

The study recommends that mobile telecommunication operators who are interested in building brand loyalty should endeavor to satisfy their customer through the provision of enhanced mobile services. Additionally, the study recommends that in order to increase customer Satisfaction, it is essential for service firms to actively manage their customers' price perceptions. The study recommends that operators offer something valuable to customers in service interaction process, such as reward and promotional offers, in order to gain customer satisfaction. Moreover, the study recommends that companies must focus on those attributes of customer satisfaction.

\section{References}

i. Adrian Payne \&PennieFrow (2005), 'A Strategic Framework for Customer Relationship

ii. Management'. Journal of Marketing Vol. 69, pp 167-176.

iii. Ahn, J.H., Han, S.P., and Lee. U.S. (2006), 'Customer churn analysis: Churn determinants and Andaleeb, S. S. (1996). An Experimental Investigation of Satisfaction and Commitment

iv. Anderson, E. and Sullivan, M.W. (1993). The Antecedents and Consequences of Customer

v. Satisfaction for Firms. Marketing Science, Vol. 12(2), pp. 125-43.

vi. Anderson, E., Fornell, C., and Lehmann, D. R. (1994). Customer Satisfaction,

vii. Market Share, and Profitability: Finding from Sweden. Journal of Marketing, 58(July), pp.53-66.

viii. Anderson, E., Fornell, C., \& Rust, R. (1997). Customer Satisfaction, Productivity, and Profitability: Differences between goods and services. Marketing science,16(2),129-145.

ix. Ang, L. and Buttle, F. (2006). Customer retention management processes - a quantitative study. European Journal of Marketing. 40(1/2): 83-99.

x. Antreas D.A. andOpoulos AI (2003). Modeling customer satisfaction in telecommunication: Assessing the multiple transaction points on perceived overall performance of the provider. Product Operational Management, 12(2): 224-245.

xi. Arora, K.C. (2007). Total Quality Management. New Delhi: S. K. Kataria\& Sons.

xii. Babbie, E. (2011). The Basics of Social Research (5th ed.). Belmont, California, USA: Cengage Learning.

xiii. Bagozzi, Richard P. and Youjae Yi (1988), 'On the Evaluation of Structural Equation Models,' Journal of the Academy of Marketing Science, 16 (Winter), 74-94.

xiv. Baron, R. M., \& Kenny, D. A. (1986). The moderator-mediator variable distinction in social psychological research: Conceptual, strategic, and statistical considerations. Journal of Personality and Social Psychology, 51, 1173-1182.

xv. Barsky, J. (1995), World-Class Customer Satisfaction, Irwin Professional, Burr Ridge, IL.

xvi. Bateson and Hoffman (2002), Essentials of Service Marketing: Concepts and CasesBerry, W. D., \& Feldman, S. (1985). Multiple Regressions in Practice. Sage University

xvii. Paper Series on Quantitative Applications in the Social Sciences, series No. 07-050). Newbury Park, CA: Sage.

xviii. Besterfield, D.H. (1994), Quality Control, Prentice-Hall, Englewood Cliffs, NJ.

xix. Bill Karakostas, DimitrisKardaras, Eleutherios Papathanassiou (August 2004),'The state of CRM adoption by the financial services in the UK, an empirical investigation'. Science Direct, Information and management 42 p853863.

xx. Bolton, R.N. \& Drew, J. (1991). A multistage model of customers' assessments of service quality and Value. Journal of consumer research, 17(4), 875-884.

xxi. Boulding, William, Ajay Kalra, Richard Staelin, and Valarie Zeithaml (1993), 'A Dynamic Process Model of Service Quality: From Expectations to Behavioral Intentions, 'Journal of Marketing Research, 30 (February), 7-27.

xxii. Brown S.A. and Gulycz, M. (2001). Customer relationship management: A strategic imperative in the world of ebusiness: New York: Wiley.

xxiii. Bult, Jan Roelf and Tom Wansbeek (1995), 'Optimal Selection for Direct Mail,' Marketing Science, 14 (4), 378-95. 
xxiv. Buttle, F. (2004). Customer Relationship Management: Concepts and Tools. Elsevier: Oxford.

xxv. Castillo et, al (2009). Understanding Qualitative and Quantitative Research Paradigms

xxvi. Chakrabarty, S., Whitten, D. \& Green, K. (2007). Understanding Service Quality and

xxvii. Chang, Tung-Zong and Albert R. Wildt. (1994). 'Price, Product Information, and Purchase Intention: An Empirical Study,' Journal of the Academy of Marketing Science,22(1): 16 -27.

xxviii. Choi TY, Chu R, (2001). Determinants of hotel guests" satisfaction and repeat patronage in Hong Kong hotel industry. Int. J. Hosp. Manage., 20: 277-297.

xxix. Churchill, G. A., and Surprenant, C. (1982). An Investigation into the Determinants of

xxx. Consumer Satisfaction. Journal of Market Research, Vol. 19, pp. 491-504.

xxxi. Cohen, J., \& Cohen, P. (1983). Applied multiple regression/correlation analysis for the

xxxii. behavioral sciences. Hillsdale, NJ: Lawrence Erlbaum Associates, Inc.

xxxiii. Cooper and Schindler (2003; 2007) Business Research Methods (10th ed.). New York: McGraw- Hill Irwin

xxxiv. Coviello, N.E., Brodie, R.J., Danaher, P.J. and Johnston, W.J. (2002). How firms relate to their markets: An empirical examination of contemporary marketing practices. Journal of Marketing. 66(3): 33-46.

xxxv. Creswell, J. W. (2003). Qualitative, quantitative, and mixed methods approach (2nd ed.). Thousand Oaks, CA: Sage.

xxxvi. Cronin, J. and Taylor, A. (1992). Measuring service quality: A re-examination and extension. Journal of Marketing, 56: 55-68.

xxxvii. Cronin, J., \&Taylor, S. (1994). SERVPERF versus SERVQUAL: Reconciling performance-based and perceptionsminus-expectations measurement of service quality. Journal of Marketing, 58(1), 125-131.

xxxviii. Crosby, Lawrence A., Kenneth R. Evans, and Deborah Cowles (1990), 'Relationship Quality in Services Selling: An Interpersonal Influence Perspective,' Journal of Marketing, 54 (July), 68-81.

xxxix. Dall'OlmoRiely et al (1997), 'The Variability of Attitudinal Repeat- Rates', International Journal of Research in Marketing, 14, 5, 437-450.

xl. Deighton, John (2000), 'Frequency Programs in Service Industries, 'in Handbook of Services Marketing and Management, T. Swartzand D. Iacobucci, eds. London: Sage Publications, 401-408.

xli. Dick, Alan S. and KunalBasu (1994), 'Customer Loyalty: Towardan Integrated

xlii. Conceptual Framework,' Journal of the Academy of Marketing Science, 22 (Spring), 99-113.

xliii. Djiofack, Z., C. and Keck, A. (2009). Telecommunications Services in Africa: The Economic Growth. World Development 37(5): 9.

xliv. Dowling, Grahame R. and Mark Uncles (1997), 'Do Customer Loyalty Programs Really Work?' Sloan Management Review,38 (Summer), 71-82.

xlv. Drèze, Xavier and Stephen J. Hoch (1998), 'Exploiting the Installed Base Using Cross

xlvi. Merchandising and Category Destination Programs,' International Journal of Research in Marketing, 15 (5), $459-$ 71.

xlvii. Egan, J. (2001). Relationship Marketing: Exploring Relational Strategies in Marketing,

xlviii. Emmanuel Toili (2011). 'Collymore Next Safaricom CEO'. Daily Nation.

xlix. Fecikova, I. (2004), 'An index method for measurement of customer satisfaction', The TQM Magazine, Vol 16 No. 1, pp. 57-66.

l. Fournier, Susan and Julie L. Yao (1997), 'Reviving Brand Loyalty: A Reconceptualization within the Framework of Consumer-Brand Relationships', International Journal of Research in Marketing, 14, 5, 451-472.

li. Fournier, Susan, Susan Dobscha and David Glen Mick (1998), 'Preventing the Premature Death of Relationship Marketing', Harvard Business Review, (January-February), pages?

lii. Gay, T. (1990), Social Research Methods. New Delhi: Prentice Hall.

liii. George M. Zinkhan and A. Parasuraman, (2002), 'Marketing to and Serving Customers through the Internet: An Overview and Research Agenda', Journal of the Academy of Marketing Science No.30; pp 286

liv. Ghavami AO (2006). The Impact of CRM on Customer Retention. Masters Thesis. Lulea

lv. University of Technology.

lvi. Grönroos, C. (2004). The Relationship Marketing Process: Communication, Interaction,

lvii. Gruen TW, Summers JO, Acito F, (2000). Relationship marketing activities, commitment, and membership behaviors in professional associations. J. Mark., 64(3): 34-49.

lviii. Gupta, S. and Zeithaml, V. (2006). Customer metrics and their impact on financial performance. Marketing Science, 25(6): 718-739.

lix. Gustafsson, A., Johnson, M.D., and Roos, I. (2005), 'The Effects of Customer Satisfaction, Hall.

lx. Hair, J. F., Anderson, R. E., \&Tatham, R. L. (1995). Multivariate data analysis with Readings (4 ${ }^{\text {th }}$ Ed.). Engelwood Cliff: Prentice-Hall International.

lxi. Hammond, Kathy (1997), Brand Loyalty for Frequently Bought Goods. London Business

lxii. School: Unpublished PhD thesis.

lxiii. Hart et al. (1999), 'Are Loyalty Schemes a Manifestation of Relationship Marketing?' Journal of Marketing Management, 15, 6, 541-562.

lxiv. Herrmann, A., Xia, L., Monroe, K.B., and Huber. F., (2007) 'The Influence of Price Fairness on Customer Satisfaction: The empirical test in the context of automobilePurchases. Journal of Product \& Brand Management, Vol. 16 Iss: 1, pp.49 - 58 
lxv. Hoekstra, Janny C., Peter S.H. Leeflang, and Dick R. Wittink (1999), 'The Customer Concept: The Basis for a New Marketing Paradigm,' Journal of Market-Focused Management, 4 (1),43-76.

lxvi. Honts, R. and Hanson, J. (2011). Maximizing customer retention, a strategic approach to effective churn management. Accenture White Paper

lxvii. Hoots, M., (2005). Customer relationship management for facility managers. Journal of Facilities Management, 3(4),346-361

lxviii. Horne, Suzanne and Steve Worthington (1999), 'The Affinity Credit Card Relationship: Can it Really be Mutually Beneficial?', Journal of Marketing Management,15, 7, 603-616.

lxix. Hunt, K. H. (1977). Conceptualization and Measurement of Consumer Satisfaction(ed.), Cambridge, MA: Marketing Science Institute Information Systems,(Winter 2007-2008), 1-15.

lxx. Jacobs, W. and Randy, S. (1999). Measuring Service Quality: A re-examination and extension. Journal of Marketing, 56, pp 55-68.

lxxi. Janiszewski, C. (2009). The consumer experiences. Association for consumer research. University of Florida.

lxxii. Jean, C. and Jacques, T. (2008). Continuous Improvement in Public Services - A Way Forward, Managing Service Quality, 8(5): 339-349.

lxxiii. Jun Wu (2008) 'Customer Relationship Management in Practice: A case study of Hi-tech company from China', Service Systems and Service Management, International Conference, Sch. of Econ. \& Manage. Beijing University of Posts \& Telecommunication, Beijing.

lxxiv. Kanji, G. and Moura, P. (2002), 'Kanji's business scorecard', Total Quality

lxxv. Management, Vol.13 No. 1, pp. 13-27.

lxxvi. Kannan, and Mathew D. Bramlett (2000), 'Implications of Loyalty Program Membership and Service Experiences for Customer Retention and Value,' Journal of the Academy of Marketing Science, 28 (Winter), 95-108.

lxxvii. Kano, N. (2007). Guide to TQM in Service Industries. Tokyo: Asian Productivity Organization.

lxxviii. Kapferer, Jean-Noël (1999). Strategic Brand Management. $2^{\text {nd }}$ Edition. London: KoganPage.

lxxix. Kerin, R.A., Hartley, S.W., \&Rudelius, W. (2009). Marketing (9th ed.). Boston: McGraw-Hill Irwin.

lxxx. Kim WG, Han JS, Lee E, (2001). Effects of relationship marketing on repeat purchase and word of mouth. J. Hosp. Tourism Res., 25(3): 272-288.

lxxxi. Kim, B., M. Shi and K. Srinivasan (2001). \Reward programs and tacit collusion, 'Marketing Science20(2): 99-120.

lxxxii. Kim, M.K., Park, M.C., and Jeong, D.H. (2004) 'The effects of customer satisfaction and

lxxxiii. Kivetz, Simonson (2002), 'Promotion Reactance: The Role of Effort-Reward Congruity,' Journal of Consumer Research, 31 (4), 725-737.

lxxxiv. Klemperer, Paul (1995). 'Competition When Consumers Have Switching Costs: An Overview with Applications to Industrial Organization, Macro Economics, and International Trade,'

lxxxv. Kopalle, Praveen and Scott A. Neslin (2003). 'The Economic Viability of Frequency Reward Programs in a Strategic Competitive Environment,' Review of Marketing Science, (accessed April16, 2004), available at http://www.bepress.com/romsjournal/vol1/iss1/art1].

lxxxvi. Kothari, C. R. (2007). Research Methodology: Methods and Techniques. New Delhi:

lxxxvii. WishwaPrakashan.

lxxxviii. Kotler P, Keller K, (2006). Marketing Management. 12 ${ }^{\text {th }}$ ed. New Jersey: Pearson Prentice Hall.

lxxxix. Kotler, P. \& Armstrong, G. (2010), 'Principles of Marketing', 13th ed. New Jersey: Prentice.

xc. Kritsonis W. A., \&Hurton, L (2008). Practical Application for Educational Research and Basic Statistics. Houston, Texas: National Forum Journals

xci. Kukar-Kinney, M., Xia, L, Monroe, L.B., (2007) 'Consumers' perceptions of the fairness

xcii. Kumar, V., Andrew, J.P. and Robert, P.L. (2007). How valuable is word of mouth? Harvard Business Review, 85(10): 139-146.

xciii. Kuo, Y.F., Wu, C.M. and Deng, W.J. (2009), Computers in Human Behavior, Volume 25, Issue.

xciv. Lam T, Zhang H, (1999). Service quality of travel agents: the case of travel agents in Hong Kong. Tourism Manage., 20: 341-349.

xcv. Lam, S.Y., Shankar, V., Erramilli, M.K., \& Murthy, B. (2004). Customer value, satisfaction, loyalty, and switching costs: An illustration from a business-to-business service context. Journal of the academy of Marketing Science, 32(3), 293-311.

xcvi. Larivie`re, B. and Poel, D. V. D (2005). Predicting customer retention and profitability

xcvii. by using random forests and regression forests techniques. Expert Systems with Applications. 29 (2): 472484.

xcviii. Latham, Garry P. and Edwin A. Locke (1991). 'Self-Regulation through Goal

xcix. Setting,' Organizational Behavior and Human Decision Processes, 50 (2), 212-47.

c. Lemon KN, Zeithaml VA, (2001). What drives Customer Equity? Mark. Manage.,10: 20-25.

ci. Lemon, Katherine, Tiffany Barnett White, and Russell Winer (2002). 'Dynamic

cii. Customer Relationship Management,' Journal of Marketing, 66 (January), 1-14

ciii. Levesque, Terrence and Gordon H. G. McDougall (1999),Determinants of Customer Satisfaction in Retail Banking, International Journal of Bank Marketing, 14(7), 12-20.

civ. Liu, C. Y. (2009). Customer Satisfaction in the service sector, Tokyo: Asian Productivity Organization.

cv. Lommeruda, K. E. and Sørgard, L. (2003), 'Entry in telecommunication: Customer Loyalty.

cvi. Louviere, J.J., Hensher, D. A. and Swait, J. (2000).Stated choice methods and applications. New York: Cambridge University Press. 
cvii. Malhotra, N. K., and Birks D. (2007). Common method variance in IS research: A comparison of alternative approaches and a reanalysis of past research. Management Science, 52,1865-1883. (December) doi:10.1287/mnsc.1060.0597.

cviii. Martin-Consuegra, D., Molina, A. and Esteban, A., (2007), 'An Integrated Model of Price, McGraw-Hill.

cix. Mihelis, G., Grigoroudis, E., Siskos, Y., Politis, Y., and Malandrakis, Y. (2001). Customer Satisfaction Measurement in the Private Bank Sector, European Journal of Operational Research, 130 (2), pp. 347-360.

cx. Mike Hoot, (2005) 'Customer Relationship Management For Facility Managers', Journal of facilities management, 2005, 3,4 ABO/INFORM Global pg.346.

cxi. Morgan, Robert M. and Shelby D. Hunt (1994), 'The Commitment-Trust Theory of Relationship Marketing, 'Journal of Marketing, 58 (July), 20-38

cxii. Naichianas et al (1996) Research Methods in Social Sciences, $5^{\text {th }}$ ed., Arnold, Santa crux

cxiii. Ndubisi, N., and Chan, K. (2005).Factorail and Discriminant Analyses of the

cxiv. Underpinnings of Relationship Marketing and Customer Satisfaction. International Journal of Bank Marketing, Vol. 23, No.7, pp. 542-557.

cxv. Nokia, (2010) Kenya Telecommunications Sector Performance Review: 1999 2003' Research ICT Africa Report cxvi. Nunnally, J. C. (1978). Psychometric Theory. New York: McGraw-Hill

cxvii. O’Brien, Louise and Charles Jones (1995), 'Do Rewards Really Create Loyalty?' Harvard Business Review, 73 (May-June),75-82.

cxviii. Oliver, R.L. (1988; 1997). Satisfaction: A behavioral perspective on the consumer. New York: McGraw-Hill.

cxix. Oliver, R.L. (1993). A conceptual model of service quality and service satisfaction:

cxx. Compatible goals, different concepts. In T.A. Swartz, D.E. Bowen, \& S.W. Brown (Eds.), Advances in services marketing and Management (pp. 65-85). Greenwich, CT: JAI Press.

cxxi. Olshavsky, R.W., and Miller, J.A. (1972).Consumer Expectations, Product Performance, and Perceived Product Quality. Journal of Marketing Research, Vol. IX(February), pp. 19-21.

cxxii. Osborne, J. W., Christensen, W. R., \& Gunter, J. (April, 2001). Educational Psychology from a Statistician's Perspective: A Review of the Power and Goodness of Educational Psychology Research.

cxxiii. Ostrom, A., \&Iacobucci, D. (1995). Consumer trade-offs and the evaluation of services. Journal of Marketing, 59(1), 17-28.

cxxiv. Papper Don and Marth Rogers (2004). 'Managing Customer Relationship', Harvard 3Business Review', 77 pp 151-60.

cxxv. Parasuraman, A., Berry, L.L. and Zeithaml, V.A. (1998). Guidelines for Conduction Service Quality Research, Marketing Research, 2(4): 34-44.

cxxvi. Parker, C., and Mathews, B.P. (2001). Customer Satisfaction: Contrasting Academic and Consumers' Interpretations. Marketing Intelligence and Planning, Vol. 19, No.1,pp. 38-44.

cxxvii. Pedhazur, E. J., (1997). Multiple Regression in Behavioral Research (3 ${ }^{\text {rd }}$ ed.). Orlando, FL:Harcourt Brace.

cxxviii. Peng, Leong Yow \& Wang, Qing (2006). Impact of Relationship Marketing Tactics (RMTs) on switchers and stayers in a competitive service industry. Journal of marketingmanagement, 22, pp 25-59.

cxxix. Peter Verhoef, (2003), Understanding of Customer Relationship Management Efforts on Customer Retention and Customer Share Development Pine, Joseph B, and James H. Gilmore (1999), The Experience Economy: Work is Theatre and every Business a Stage, Boston, MA: Harvard Business School Press.

cxxx. Preacher, K.J., \& Hayes, A.F. (2004).SPSS and SAS procedures for estimating indirect effects in simple mediation models Behavior Research Methods, Instruments, \& Computers, 36, 717-731.

cxxxi. Rahimi.and Gwinner, K. P. (2008). Internet Retail Customer Loyalty: The Mediating

cxxxii. Role of Relational Experience: International Journal of Service Industry Management, Vol. 14 Iss: 5, pp.483 - 500

cxxxiii. Reichheld, F.F. \&Sasser, Jr., W.E. (1990; 1996). Zero defections. Quality comes to services. Harvard Business Review,68(5), 105-111.

cxxxiv. Rivie`re, B., Cadotte, E.R., Woodruff, R.B and Jenkins, R.C. (2006). Developing zones of tolerance for managing passenger rails services quality, International Journal of Quality and Reliability Management, 24 (1): 7-31.

cxxxv. Robson (2002) Business research methods. Oxford University Press.

cxxxvi. Roehm, Michelle L., Ellen BolmanPullins, and Harper A. RoehmJr. (2002), 'Designing Loyalty Building Programs for Packaged Goods Brands,' Journal of Marketing Research, 39 (May), 202213.

cxxxvii. Roos, I., Gustafsson, A., \&Edvardsson, B. (2006). Defining relationship quality for customer- driven business development. International Journal of service Industry Management, 17(2), 207-223.

cxxxviii. Ryals, L.J. and Knox, S. (2005). Measuring risk-adjusted customer lifetime value and its impact on relationship marketing strategies and shareholder value. European Journal of Marketing. 39 (5/6): 456-472.

cxxxix. SamitChakravorti (2006) 'CRM a Content Analysis of Issues and Best Practices', Journal of Consumer Marketing Vol. No 20 pp 385-398.

cxl. Saunders et. al $(2000 ; 2007)$, Research Methods for Business Students $2^{\text {nd }}$ Edition, Financial times/prentice Hall.

cxli. Shankar, V., Smith, A., \&Rangaswamy, A (2003). Customer satisfaction and loyalty in online and offline environments. International Journal of Research in Marketing, 20 (2), 153-175.

cxlii. Sharp, B. and A. Sharp, (1997). Loyalty Programs and Their Impact on Repeat-Purchase

cxliii. Loyalty Patterns. International Journal of Research in Marketing 14 (No. 5), 473-486.

cxliv. Singh, H. (2006). The importance of customer satisfaction in relation to customer loyalty and retention. UCTI Working Paper. Asia Pacific University College of Technology and Innovation, Malaysia. 
cxlv. Sirdeshmukh, Sigh, and Sabol (2002). Understanding the structure of customers' satisfaction evaluations of service Delivery.

cxlvi. Smith, J.B., \& Barclay, D.W. (1997). The effects of organizational differences and trust on the effectiveness of selling partner relationships. Journal of Marketing, 61(1), 3-21.

cxlvii. Soderlund, M., and Rosengren, S. (2008), 'Revisiting the smiling service Worker and customer.

cxlviii. Soman, Dilip (1998), 'The Illusion of Delayed Incentives: Evaluating Future Effort-Money.

cxlix. Somekh and Lewin (2005). Research Methods in social Sciences.

cl. Spreng, R. A., \&Mackoy, R. D. (1996). An empirical examination of a model of perceived service quality and satisfaction. Journal of Retailing, 72(2): 201-214.

cli. Spreng, R. A., MacKenzie, S. B., and Olshavsky, R. W. (1996). A Reexamination of the Determinants of Consumer Satisfaction. Journal of Marketing, Vol. 60 (July), pp.15-32.

clii. Sprowls, R.C., and Asimow, M. (1962). A Model of Customer Behavior for the Task Manufacturing Corporation. Management Science, Vol. 8 (3), pp. 311-324.

cliii. Stanton, W. J., Michael J. E, and Bruce J. W. (1994) Fundamentals in Marketing. 10th ed.

cliv. Stengel, G. (2003). Ten tips for measuring and improving performance. Stengel Solutions.

clv. Stone, M., Woodcock, N., and Machtynger, L. (2000). Customer Relationship Marketing: switching barrier on customer loyalty in Korean mobile telecommunication services'

clvi. Sullivian T. J (2001). Methods of Social Research. Fort Worth, TX

clvii. Tabachnick, B. G., Fidell, L. S. (2001). Using Multivariate Statistics (4th ed.). Needham Heights, MA: Allyn and Bacon

clviii. Teas, F. (1994). Closeness, Strength and Satisfaction: Examining Nature of Relationships between providers of Financial Service and their Retail Customers, Psychology and Marketing, 14 (8): 765790.

clix. Terblanche, N.S. and Hofmeyr, J. (2005). A study of two customer retention measures: the American customer satisfaction index and the conversion model.

clx. Trasorras, R., Weinstein, A. and Abratt, R. (2009).Value, satisfaction, loyalty and retention in professional services. Marketing Intelligence \& Planning. 27 (5): 615-632.

clxi. Tseng, Yi Ming (2007). The Impacts of Relationship Marketing Tactics on Relationship Quality in Service Industry. The business Review, Cambrdge, Vol, 7 number 2.

clxii. Turel, O., and Serenko, A. (2006), 'Satisfaction with mobile services in Canada: An empirical

clxiii. Turnbull, P., \&Moustakatos, T. (1996) Marketing and investment banking: relationships \& competitive advantage. International Journal of Bank Marketing, 14, 38-49

clxiv. Uncles, Mark D., Kathy Hammond, Andrew S. C. Ehrenberg and R. E. Davis((1994), 'A Replication Study of Two Brand-Loyalty Measures', European.

clxv. Wassenaar, V., Andaleeb, S. S. and Conway, C. (2005). Customer Satisfaction in the

clxvi. Restaurant Industry: An Examination of the Transaction-specific model. Journal of Services Marketing, 20 (1): 311.

clxvii. Weilbacher, W. M. (1993), Brand Marketing. Linconwood, IL: NTC Books, Ch. 7.

clxviii. Weiner, B. (1996). An attribution theory of motivation and emotion. New York: Springer-Verlag.

clxix. WiersmaW(1995). Research Methods in Education: An Introduction (6 ${ }^{\text {th }}$ Ed)

clxx. Winter, T. (1999). An Exploratory study of service Quality In The Malaysian Public Service, International Journal of Quality and Reliability Management, 2007, 24(2): 177-190.

clxxi. Woo, K. and Fock, H.K.Y. (2004). Retaining and divesting customers: an exploratory study of right customers, atrisk right customers, and wrong customers. Journal of Services Marketing. 18 (3): 187-197.

clxxii. Wu, D. and Pan, A. (2009). A critical Approach to Examining the Effects of Service Failures in Customer Relationship: The case of Swedish and U. S. Airlines Journal of Travel Research,7: 35 - 40.

clxxiii. Xia, L., Monroe, K. ,\& Cox, J..(2004). 'The Price Is Unfair! A Conceptual Framework of Price fairness Perceptions

clxxiv. Zeithaml, V.A., Berry, L.L., and Parasuraman, A. (1996).The behavioral consequences of

clxxv. service quality. Journal of Marketing, 60(2): 31-46.

clxxvi. Zeithaml, Valarie A., Leonard L. Berry, and A. Parasuraman (2000),'The Behavioral Consequences of Service Quality,' Journal of Marketing, 60 (April), 31-46.

clxxvii. Zhang, Z. John, Aradhna Krishna, and Sanjay K. Dhar (1999; 2000),'The Optimal Choice of Promotional Vehicles, 'ManagementScience, 46 (3), 348-62

clxxviii. Zikmund, W. G., Babin, B.J., Carr, J. C. and Griffin, M. (2010).Business Research Methods (8th Ed.). Canada: SouthWestern, Cengage, Learning Canada. 